\title{
DZIAŁALNOŚĆ MISJONARSKA ŚW. PIOTRA POZA PALESTYNĄ W ŚWIETLE LITERATURY NOWOTESTAMENTOWEJ
}

Euzebiusz z Cezarei w Historii Kościelnej podaje, że za panowania Klaudiusza Piotr apostoł udał się do Rzymu i zaniósł tam bezcenny skarb duchowego światła. ${ }^{1}$ Według łacińskiego przekładu Kroniki Euzebiusza, dokonanego przez św. Hieronima, św. Piotr udał się tam dokładnie w drugim roku panowania Klaudiusza, czyli w 42 r. po Chr., oraz głosił Rzymianom Ewangelię przez dwadzieścia pięć lat. ${ }^{2}$ Sam św. Hieronim natomiast, opierając się na przekazach Euzebiusza, w swym dziele $O$ znakomitych mężach pisze, że Szymon Piotr był biskupem Rzymu ,przez dwadzieścia pięć lat, do ostatniego roku Nerona". ${ }^{3}$

Informację tę jednak, niestety, podważają niektóre teksty Nowego Testamentu. A mianowicie z Dz 15, 1-29 i Ga 2, 1-14 dowiadujemy się, że św. Piotr uczestniczył w tzw. Soborze Jerozolimskim, który odbył się ok. 49 r., a później udał się na jakiś czas do Antiochii. W Liście do Rzymian (pisanym na początku 56 r.), św. Paweł nawet jednym słowem nie wspomina o Piotrze. Choć dobrze zna sytuację adresatów swego pisma i w jego końcowej części pozdrawia aż 26 osób (Rz 16, 3-16), to jednak nigdzie nie wymienia Piotra. Gdyby ten apostoł,

Euzebiusz z Ce zarei, Historia Kościelna 12, 4, 6.

2 Zob. Die Chronik des Hieronymus, w: R. He $1 \mathrm{~m}$ (red.), Eusebius Werke, t. 7, Berlin 1956, 261F.

3 Tekst polski: św. H i e r o n i m, O znakomitych mężach. Eteria. Pielgrzymka do miejsc świętych, tłum. W. S z oł d r s k i, Pisma Starochrześcijańskich Pisarzy 6, Warszawa 1970, s. 27. 
który w Ga 2, 9 uzyskał tytuł filaru Kościoła, był wówczas obecny w Rzymie, św. Paweł na pewno by o tym wiedział i nie pominąłby go wśród pozdrawianych osób. Jest ponadto wiadome, że Żydzi zostali wysiedleni ze stolicy imperium za panowania cesarza Klaudiusza i mogli tam powrócić dopiero po jego śmierci, czyli w 54 r. Co więcej, sam św. Hieronim w swym cytowanym wyżej fragmencie $O z n a-$ komitych mężach umieszcza tekst wewnętrznie sprzeczny, pisząc bowiem o dwudziestopięcioletnim pontyfikacie św. Piotra, nieco wcześniej wyjaśnia, że on przybył do Rzymu ,po rządach biskupich w Kościele Antiocheńskim i nauczaniu Żydów (...) w Poncie, Galacji, Kapadocji, Azji i Bitynii”. Jeśli opuścił Jerozolimę za panowania Agryppy I (Dz 12, 17), czyli ok. 42 r., to po tylu podróżach apostolskich nie mógł przybyć do Rzymu w tym samym roku.

Biorąc pod uwagę te i inne mniej istotne argumenty, wielu uczonych protestanckich uważa, że Piotr nigdy nie przebywał w Rzymie. ${ }^{4}$ Egzegeci katoliccy odrzucają tak ekstremalne stanowisko, ale biorąc na serio zarówno dane nowotestamentowe, jak też świadectwa ojców Kościoła, wysuwają hipotezę, że mógł on przybyć do wspólnoty rozwijającej się w stolicy cesarstwa dopiero po $56 \mathrm{r}$. i działał w niej do chwili swej śmierci, czyli do ok. 65 r. ${ }^{5}$ Hipoteza ta, mająca mocne podstawy biblijne, rodzi jednak pytanie: Gdzie przebywał i działał św. Piotr do chwili swego przybycia do Rzymu? W całym Nowym Testamencie są, niestety, tylko 4 krótkie teksty, które mogą pomóc udzielić bardzo ogólnej odpowiedzi na to pytanie: 1Kor 1, 12 (brany łącznie z 3, 22); 9, 5; Ga 2, 11-14; 1P 1, 1. Wersety te, ze względu na swą zwięzłość i wieloznaczność, stały się przedmiotem wielu dyskusji uczonych, którzy w ich interpretacji nie są jednomyślni. W artykule tym chcemy dokonać przeglądu ich opinii oraz zastanowić się, czy teksty te są w stanie pomóc w wytropieniu śladów misjonarskiej

4 Zwraca na to uwagę M. G r a n t, Święty Piotr, Warszawa 2001, s. 143-145.

Możliwość taką przyjmuje, po dokonaniu dokładnej analizy danych biblijnych i pozabiblijnych, W. R a k o c y, Lata pobytu Apostoła Piotra w Rzymie (rys historyczny), w: S. S z y m i k, H. O r d o n (red.), Opoka Kościoła Chrystusowego. Bibliści KUL w 25. rocznice pontyfikatu Jana Pawła II, Lublin 2004, s. 158-159. 
działalności św. Piotra, zakończonej przybyciem do stolicy Cesarstwa Rzymskiego.

\section{Milczenie Łukasza na temat dzialalności Piotra apostoła poza Palestyną}

Święty Łukasz w Dz 1-12 wiele miejsca poświęca działalności św. Piotra w Kościele pierwotnym, ukazując jednocześnie jego wielki autorytet we wspólnocie uczniów Jezusa. Pisze, że to właśnie on wyszedł z inicjatywą uzupełnienia Kolegium Dwunastu, uszczuplonego po śmierci Judasza (Dz 1, 15-22). Przytacza cztery jego katechezy/ mowy wygłoszone po zesłaniu Ducha Świętego na terenie Jerozolimy $(2,14-36 ; 3,12-26 ; 4,8-12 ; 5,29-32)$. Wspomina cuda dokonywane przez niego zarówno w Jerozolimie, jak też w innych miastach Judei (3, 4-11; 5, 15; 9, 32-43). Podkreśla jego odwagę w głoszeniu Ewangelii członkom Sanhedrynu, nastawionym wrogo do wyznawców Chrystusa $(4,13-22)$. Na koniec wreszcie przypomina swym czytelnikom, że to on jako pierwszy przyjął pogan do wspólnoty wierzących i swą postawą wykazał, że przed Bogiem wszyscy ludzie mają tę samą godność $(10,10-48 ; 11,1-17)$.

Wszystkie opisy działalności św. Piotra na terenie Judei mają swój finał w Dz 12, 1-15. Fragment ten ukazuje prześladowania, które wszczął Herod Agryppa I, a które zostały wymierzone przede wszystkim przeciwko chrześcijańskim liderom. Ich skutkiem było ścięcie Jakuba, brata Jana, oraz uwięzienie Piotra, które być może również skończyłoby się jego śmiercią, gdyby nie interwencja samego Boga, dzięki której Piotr został cudownie wyzwolony z rąk Heroda. Po wyjściu z więzienia Piotr udał się do domu Marii, matki Jana Marka, gdzie chrześcijanie zebrali się, by się modlić za niego. Po krótkiej wzmiance o spotkaniu z nimi św. Łukasz oznajmia, że zaraz potem Piotr ,udał się gdzie indziej” (Dz 12, 17). Wraz z tą decyzją Piotr prawie zupełnie znika z kart Dziejów Apostolskich. Pojawia się jeszcze na krótko w Dz 15, 7-12, w prezentacji obrad tzw. Soboru Jerozolimskiego, na którym znacząco wpłynął na treść dekretu apostolskiego, dotyczącego religijnych obowiązków nakładanych 
na pogan przyjmujących wiarę w Chrystusa. Fragment ten jednak jest już tylko drobnym epizodem w tekście poświęconym niemal wyłącznie misyjnej działalności św. Pawła.

Wielu uczonych, komentując Dz 12, 17 lub nawiązując do tego tajemniczego zdania: „udał się gdzie indziej”, zastanawiało się, gdzie mógł pójść św. Piotr, aby schronić się przed gniewem Heroda. Niektórzy współcześni egzegeci wciąż uznają wiarygodność informacji Euzebiusza i uważają, że właśnie wtedy św. Piotr udał się do Rzymu, tam założył wspólnotę chrześcijańską i został pierwszym jej biskupem. ${ }^{6}$ Nieliczni wysuwają hipotezę, że stwierdzenie „udał się gdzie indziej” jest Łukaszową metaforą na określenie męczeńskiej śmierci św. Piotra, która mogła nastąpić już w Jerozolimie. ${ }^{7}$ Natomiast zdecydowana większość uczonych (nie tylko protestanckich, ale też katolickich) nie podziela żadnej z tych dwóch skrajnych opinii. Podają oni jednak wiele różnych propozycji, które można umieścić w czterech grupach.

1. Po opuszczeniu Jerozolimy Piotr udał się do miast położonych nad brzegami Morza Śródziemnego, w których wcześniej działał (zob. Dz 9, 32-43), aby tam kontynuować swą pracę apostolską. ${ }^{8}$ Słabość tej hipotezy polega na tym, że terytoria te w tym czasie znajdowały się pod jurysdykcją Heroda Agryppy I, który w latach 41-44 był prokuratorem Judei. Pozostając tam, Piotr nadal byłby narażony na jego gniew

6 Należy do nich np. E. J a c qu i e r, Les Actes des Apôtres, Paris 1926, s. 369; J. R e n i é, Actes des Apôtres, Paris 1949, s. 177-178; S. D o c k x, Essai de chronologie pétrinienne, Recherches de Science Religieuse 62/1974, s. 221-241; C.P. T h i e d e, Babylon, der andere Ort: Anmerkungen zu 1 Petr 5,13 und Apg 12,17, Biblica 67/1986, s. 537; t e n ż e, Simon Pietro dalla Galilea a Roma, Milano 1999, s. 228-234; G. B r a y, Romans, Ancient Christian Commentary on Scripture. New Testament 6, Chicago-London 1998, s. 363.

7 Zob. D.F. R o b i n s o n, Where and When Did Peter Die? Journal of Biblical Literature 64/1945, s. 255-267; M. S m a 1 t z, Did Peter Die in Jerusalem? Journal of Biblical Literature 71/1952, s. 211-216; F.F. B r u c e, The Book of the Acts, Grand Rapids 1988, s. 239.

8 R.N. L o n g e n e c k e r, The Acts of the Apostles, Grand Rapids 1981, s. 207. 
i prędzej czy później zostałby ponownie aresztowany i najprawdopodobniej stracony.

2. Aby uniknąć kolejnego aresztowania, Piotr opuścił terytoria podlegające władzy Heroda Agryppy i głosił Ewangelię poza Palestyną, nie możemy jednak powiedzieć nic konkretnego o miejscu jego pobytu. ${ }^{9}$ Powrócił do Jerozolimy na Sobór Jerozolimski ok. 49 r. (Dz 15), ponieważ w tym czasie prokurator już nie żył (zmarł w 44 r.; zob. Dz 12, 18-23). ${ }^{10}$

3. Z Jerozolimy Piotr udał się bezpośrednio do Antiochii, gdzie głosił Ewangelię w szybko rozwijającej się wspólnocie chrześcijan, o czym wyraźnie świadczą wspomnienia św. Pawła, zawarte w Ga 2, 11-14. ${ }^{11}$

4. Na podstawie wzmianek o Piotrze w 1 Kor 9, 5 i Ga 2, 11-14 można przypuszczać, że stał się on wędrownym apostołem i prowadził rozległą działalność misjonarską. ${ }^{12}$ Jest możliwe, że w czasie swej wieloletniej podróży dotarł nawet do

9 J. F in e g a n, The Archeology of the New Testament. The Mediterranean World of the Early Christian Apostles, London 1981, s. 40; A. W e i s e r, Die Apostelgeschichte. Kapitel 1-12, Ökumenischer Taschenbuchkommentar zum Neuen Testament 5/1, Gütersloh-Würzburg 1981, s. 291; H. L a n g k a m m e r, Dzieje Apostolskie, Biblia Lubelska, Lublin 2008, s. 159.

10 C.S. Ke e ne r, Acts: an Exegetical Commentary, t. 2: 3:1 - 14:28, Grand Rapids 2013, s. 1953.

11 C.F. N e s b it t, What Did Become of Peter? Journal of Bible and Religion 27/1959, s. 10-16; G. S t ä h 1 i n, Die Apostelgeschichte, Das Neue Testament Deutsch 5, Göttingen $1966^{11}$, s. 170.

12 E. D ą b row s k i, Dzieje Apostolskie. Wstęp-przekład z oryginału, komentarz, Pismo Święte Nowego Testamentu 5, Poznań 1961, s. 328-329; J.D.G. D u n n, The Acts of the Apostles, Grand Rapids 1996, s. 164; C.K. B a r r e t t, A Critical and Exegetical Commentary on the Acts of the Apostles, t. I, Edinburgh 1998, s. 587; G. R o s s é, Atti degli Apostoli. Commento esegetico e teologico, Roma 1998, s. 473, przyp. 88; J.A. Fit z m y e r, The Acts of the Apostles: a New Translation with Introduction and Commentary, The Anchor Bible 31, London 2010, s. 489; J.W. P a c k e r, The Acts of the Apostles, New York 2010, s. 98. 
niektórych części Azji Mniejszej, o czym z kolei może świadczyć $1 \mathrm{P} 1,1 .^{13}$

Jest z pewnością dziwne, że Łukasz, dla którego Piotr był wielkim autorytetem, nie podaje nazwy miejsca, do którego udał się on po wyjściu z więzienia. Jest możliwe - jak twierdzą niektórzy - że nie miał na ten temat żadnych informacji. ${ }^{14}$ Można też zgodzić się z sugestią innych, że w samej narracji Dziejów Apostolskich taka informacja jest właściwie zbędna. ${ }^{15}$ Bardzo ogólne zdanie „udał się gdzie indziej" ma przede wszystkim za zadanie powiadomić czytelnika, że właśnie skończyła się działalność Piotra w Jerozolimie oraz w innych miastach Judei i Samarii. ${ }^{16}$ Odchodząc ze stolicy, nie pozostawia jednak po sobie pustego miejsca. Znamienne, że w Dz 12, 17 Łukasz ustami Piotra po raz pierwszy przedstawia Jakuba, którego w 15, 13 -21 i 21, 18 ukazuje już jako przełożonego Kościoła jerozolimskiego. Oświadcza tym samym, że Jakub jest następcą Piotra w kierowniczej funkcji pierwszej wspólnoty chrześcijańskiej, ${ }^{17}$ która stała się matką innych Kościołów.

W jego narracji werset Dz 12, 17 ma też pewien związek z nakazem misyjnym Jezusa: „Będziecie moimi świadkami w Jeruzalem i w całej Judei, i w Samarii, i aż po krańce ziemi” (Dz 1, 8). To zdanie ukazujące zwięźle program działalności Kościoła pozwala zrozumieć, że św. Łukasz nie zamierzał w swym dziele przedstawiać biografii wszystkich apostołów, lecz starał się zapoznać czytelnika z rozprzestrzenianiem się słowa Bożego od początkowej fazy, związanej z działalnością apostołów w Jerozolimie, aż do przeobrażenia

13 C.S. K e e n e r, Acts, s. 1952.

14 Por. tamże, s. 1953.

15 J. J e r v e 1 1, Die Apostelgeschichte, Kritisch-exegetischer Kommentar über das Neue Testament 3, Göttingen 1998, s. 335.

16 Tak uważa również B. W i t h e r i ng t on III, The Acts of the Apostles. A Socio-Rhetorical Commentary, Grand Rapids 1998, s. 389; G. R o s s é, Atti degli Apostoli, s. 473; C.R. H o 11 a d a y, Acts: a Commentary, Louisville 2016, s. 254.

17 Por. R.W. W a 11, Successors to 'the Twelve' According to Acts 12:1-17, Catholic Biblical Quarterly 53/1991, s. 641-642. 
się chrześcijaństwa w zjawisko o światowym zasięgu. ${ }^{18}$ Według niego, najpierw w Jeruzalem, a potem w całej Judei i Samarii głównym świadkiem Jezusa zmartwychwstałego był św. Piotr, któremu często towarzyszy również św. Jan, natomiast zadanie rozpowszechnienia Ewangelii „aż po krańce ziemi” zostało spełnione głównie dzięki działalności św. Pawła. Ponieważ osobiście mógł mu towarzyszyć w czasie jego podróży misyjnych, jego osobie i pracy apostolskiej poświęcił całą następną część swej księgi, obejmującej Dz 13-28. $\mathrm{Z}$ tego punktu widzenia zatem zdanie o opuszczeniu Jerozolimy przez Piotra pełni w narracji Dziejów Apostolskich funkcję przejścia od jednego do drugiego podmiotu opowieści. ${ }^{19}$

W egzegetycznych analizach Dz 12, 17 pojawia się też sugestia, że Łukasz nie mógł jednoznacznie podać miejsca, do którego udał się Piotr po uwolnieniu z więzienia, ponieważ później często zmieniał miejsce swego pobytu. ${ }^{20} \mathrm{~W}$ jakimś sensie idzie ona po linii podanej wyżej ostatniej hipotezy, że Piotr jako wędrowny apostoł prowadził rozległą działalność misjonarską. Można przypuszczać, że z powodu swej pokory nie zatroszczył się o to, by Marek, utrwalający na piśmie jego świadectwo o Jezusie Chrystusie, Synu Bożym (por. Mk 1, 1), lub jakiś inny jego uczeń spisał jego własne wspomnienia o pracy i podróżach misyjnych, które odbył przed dotarciem do Rzymu. Nie oznacza to jednak, że absolutnie nic nie wiemy na temat tego okresu jego życia. Jak już zostało powiedziane we wstępie do tego artykułu, znikome ślady jego działalności apostolskiej, którą prowadził w różnych częściach Cesarstwa Rzymskiego, znajdujemy w listach

18 Por. Ph. H. M e n o u d, Le plan des Actes des Apôtres, New Testament Studies 1/1954-1955, s. 50-51; G. B e to r i, Lo Spirito e l'annuncio della Parola negli Atti degli Apostoli, Rivista Biblica Italiana 35/1987, s. 420; R. K e m p i a k, „Będziecie moimi świadkami (...) aż po krańce ziemi” (Dz 1, 8). Kompozycja Dziejów Apostolskich, Scriptura Sacra 1/1997, s. 77-78.

19 Por. B. P r e t e, A. S c a g 1 i o n i, I miracoli degli Apostoli nella Chiesa delle origini, Torino 1989, s. 118.

20 Tak twierdzi O. B a u e r n fe i n d, Kommentar und Studien zur Apostelgeschichte, Wissenschaftliche Untersuchungen zum Neuen Testament 22, Tübingen 1980, s. 162. 
św. Pawła (1Kor 1, 12; 3, 22; 9, 5; Ga 2, 11-14) oraz w zagadkowym wykazie adresatów Pierwszego Listu św. Piotra (1P 1,1). W naszej analizie zajmiemy się najpierw tekstem Ga 2, 11-14.

\section{Pobyt Piotra w Antiochii Syryjskiej}

W Ga 2, 11 św. Paweł pisze: „Gdy następnie Kefas przybył do Antiochii, otwarcie mu się sprzeciwiłem, bo na to zasłużył”. W całym Nowym Testamencie jest to jedyny tekst, z którego czytelnik może się dowiedzieć, że po opuszczeniu Judei Piotr na pewno przebywał przez jakiś czas w Antiochii Syryjskiej. Ze względu na swą zwięzłość rodzi on jednak wiele pytań, wśród których na pierwszym miejscu pojawia się kwestia, kiedy i dlaczego Piotr udał się do tego właśnie miasta.

Należy najpierw stwierdzić, że trudno jest jednoznacznie określić, kiedy św. Piotr przybył do Antiochii. Zahn próbuje w swym komentarzu udowodnić, że miało to miejsce jeszcze przed Soborem Jerozolimskim, ${ }^{21}$ U. Borse precyzuje, że Piotr po ucieczce z Jerozolimy, wspomnianej w Dz 12, 17, udał się bezpośrednio do Antiochii, gdzie niebawem doszło do konfliktu między Pawłem a Piotrem. ${ }^{22}$ Podobnego zdania jest H.-M. Féret, który sugeruje odczytywać tekst Ga 2, 11 w kontekście Dz 14, 28, gdzie Łukasz pisze, że Barnaba i Paweł po powrocie z pierwszej podróży misyjnej „dość długi czas spędzili wśród uczniów". Wtedy też doszło do ich spotkania z Piotrem. ${ }^{23}$ F.F. Bruce wreszcie uważa, że Dz 15, 6-29 i Ga 2, 1-10, które znacznie różnią się w swej treści, w rzeczywistości opisują dwa różne zebrania apostołów oraz że opisane przez Pawła spotkanie odbyło się przed opisanym przez Łukasza Soborem Jerozolimskim. Według niego, konflikt Pawła z Piotrem miał miejsce między tymi dwoma

${ }^{21}$ Th. Z a h n, Der Brief des Paulus an die Galater, Kommentar zum Neuen Testament 9, Leipzig 1922³ , s. 110-112.

22 U. B o r s e, Der Brief an die Galater, Regensburger Neuen Testament 9, Regensburg 1984, s. 107-111. Podobnie uważa też F.J. M a t e r a, Galatians, Sacra Pagina Series 9, Collegeville 2007, s. 85.

23 H.-M. Fé r e t, Pierre et Paul a Antioche et a Jérusalem. Le «conflit» des deux Apôtres, Paris 1955, s. 77-83. 
spotkaniami, po powrocie Barnaby i Pawła z pierwszej podróży misyjnej. ${ }^{24}$

Umieszczenie tego incydentu przed Soborem Jerozolimskim zapewne pozwala na uzyskanie bardziej logicznej sekwencji wydarzeń, ${ }^{25}$ zgodnie z którą konflikt między Piotrem a Pawłem w Antiochii stał się bezpośrednią przyczyną udania się apostołów do Jerozolimy w celu uzyskania jednoznacznego stanowiska w odniesieniu do pogan nawracających się na chrześcijaństwo. ${ }^{26}$ Mimo to jednak większość uczonych jest zdania, że Piotr przybył do Antiochii niebawem po Soborze Jerozolimskim, kiedy Paweł i Barnaba przed wyruszeniem w następną podróż misyjną nauczali tam i wraz z innymi głosili słowo Pańskie (Dz 15, 35). ${ }^{27}$ czyli ok. 50 r. Za taką kolejnością wydarzeń przemawia przede wszystkim sam tekst Ga 1-2, w którym św. Paweł chronologicznie przedstawia najważniejsze chwile swego życia po nawróceniu i spór z Piotrem umieszcza po obradach apostołów, dotyczących sposobu traktowania pogan przyjmujących Ewangelię o Chrystusie.

24 F.F. B ruce, The Epistle of Paul to the Galatians. A Commentary on the Greek Text, Exeter 1982, s. 128. Odosobnione stanowisko w tej kwestii prezentuje A. S c h l a t t e r (Die Geschichte der ersten Christenheit, Gütersloh 1926, s. 190-191), który umieszcza konflikt antiocheński między drugą a trzecią podróżą misyjną św. Pawła.

25 Por. A. M é h a t, "Quand Képhas vint à Antioche...»Que s'est-il passé entre Pierre et Paul? Lumière \& Vie 192/1989, s. 29-43; A. V a n h o y e, Lettera ai Galati. Nuova versione, introduzione e commento, Milano 2000, s. 64.

${ }^{26}$ Tak uważa G. Lü de r m a n n, Paul, Apostle to the Gentiles. Studies in Chronology, London 1984, s. 75-77.

27 Zob. m.in. H. S c h 1 i e r, Der Brief an die Galater, Kritisch-exegetischer Kommentar über das Neue Testament, Göttingen 1962, s. 82; J. E c k e r t, Die urchristliche Verkündigung im Streit zwischen Paulus und seinen Gegnern nach dem Galaterbrief, Regensburg 1971, s. 193; E. S z y m a n e k, List do Galatów. Wstęp - przekład z oryginału - komentarz, PŚNT VI/2, Poznań-Warszawa 1979, s. 60; T. H olt z, Der antiochenische Zwischenfall (Galater 2.11-14), New Testament Studies 32/1986, s. 347; J. R o h d e, Der Brief des Paulus an die Galater, Theologischer Handkommentar zum Neuen Testament 9, Berlin 1989, s. 104; K. R o m a n i k, Św. Piotr. Życie i dzieło, Katowice 1995, s. 100; M.C. d e B o e r, Galatians. A Commentary, Louisville 2011, s. 130. 
Nie da się ustalić, co było przyczyną przybycia Piotra do Antiochii, ponieważ Paweł w Liście do Galatów koncentruje się na tym, co się wydarzyło w tamtej wspólnocie, gdy Piotr był w niej obecny, ${ }^{28}$ dlatego wielu egzegetów w swych komentarzach zupełnie pomija to zagadnienie. Niektórzy jednak usiłują podać najbardziej rozsądny powód, a ich hipotezy można połączyć w cztery grupy:

1. Przybycie Piotra do Antiochii miało charakter swoistej inspekcji. Zamierzał on sprawdzić naturę ruchu chrześcijańskiego w miastach pobliskiej diaspory żydowskiejej ${ }^{29}$ bądź też sposób wprowadzania w życie postanowień Soboru Jerozolimskiego. ${ }^{30}$

2. Chodzi tu o swego rodzaju rewizytę Piotra, złożoną tym, którzy wcześniej przybyli do Jerozolimy na zebranie apostołów i na nim oficjalnie reprezentowali wspólnotę antiocheńską. ${ }^{31}$

3. Zgodnie z decyzją, o której jest mowa w Ga 2, 8, Piotr przybył do Antiochii, gdzie była duża diaspora, by tam prowadzić działalność misyjną wśród Żydów. ${ }^{32}$ Ponieważ jednak wzrastająca tam wspólnota chrześcijańska składała się zarówno z Żydów, jak też z pogan, Piotr w rezultacie swą pracą apostolską objął $\mathrm{i}$ jednych, i drugich. ${ }^{33}$

4. Była to zwykła wizyta, złożona przełożonym wspólnoty antiocheńskiej w czasie podróży do następnych miast, w których Piotr zamierzał głosić Ewangelię. ${ }^{34}$

28 Por. F. M u ß n e r, Der Galaterbrief, Herders Theologischer Kommentar zum Neuen Testament 9, Leipzig 1974, s. 137, przyp. 14.

29 N. Ta y lo r, Paul, Antioch and Jerusalem: a Study in Relationship and Authority in Earliest Christianity, Journal for the Study of NT. Supplement Series 66, Sheffield 1989, s. 123; D.J. M o o, Galatians, Baker Exegetical Commentary on the New Testament, Grand Rapids 2013, s. 145.

30 K. R o m a n i u k, Św. Piotr, s. 100.

31 J. B e c k e r, Der Brief an die Galater, w: Die Briefe an die Galater, Epheser und Kolosser, Das Neue Testament Deutsch 8/1, Göttingen 1998, s. 39.

32 B. W it h e r i n g t o n III, Grace in Galatia. A Commentary on Paul's Letter to the Galatians, Grand Rapids 1998, s. 150.

33 C.P. T h i e d e, Simon Pietro, s. 243-244.

34 H.D. B e t z, Galatians, Philadelphia 1979, s. 105; S. C i p r i a n i, Św. Piotr Apostoł, Kraków 2008, s. 138, 156; A. P i t t a, Lettera ai Galati. Introduzione, versione e commento, Bologna 2009², s. 132. 
Ta różnorodność propozycji pokazuje, że nie da się jednoznacznie określić, z jakim zamiarem Piotr przybył do Antiochii i jaką rolę odgrywał w czasie swego pobytu w tym mieście. Euzebiusz z Cezarei sugeruje w swej Historii kościelnej, że Piotr był pierwszym zwierzchnikiem Kościoła antiocheńskiego, a jego drugim następcą był Ignacy, ${ }^{35}$ ale, niestety, na innym miejscu podaje odmienną informację, gdzie nie wspominając zupełnie o Piotrze, pisze, że w Antiochii pierwszym biskupem był Ewodios, a drugim Ignacy. ${ }^{36}$ Co więcej, szczegół ten stoi w sprzeczności z inną informacją tego historyka, wspomnianą na początku niniejszego artykułu, że mianowicie przez 25 lat Piotr był biskupem Rzymu. Z tych sprzeczności można wyciągnąć wniosek, że informacje Euzebiusza w tym względzie są oparte na rozbieżnych tradycjach. M. Grant uważa, że Piotr pozostawał tam przez prawie siedem lat, być może aż do 56 r., ale zarazem stwierdza, że „przypisywanie mu przez Ojców Kościoła stanowiska pierwszego biskupa Antiochii jest anachronizmem". ${ }^{37} \mathrm{Z}$ pewnością ma rację co do owego anachronizmu, ponieważ apostołowie raczej nie pełnili urzędów przypominających późniejsze biskupstwa rezydencjalne, lecz wszyscy byli wędrownymi misjonarzami. ${ }^{38} \mathrm{Z}$ drugiej strony jednak podawany przez niego czas pobytu w Antiochii nie ma żadnego potwierdzenia w danych biblijnych i pozabiblijnych.

W Ga 2, 8 Paweł pisze, że Pan „który współdziałał z Piotrem w apostołowaniu obrzezanych, współdziałał i ze mną wśród pogan”. Czyniąc takie porównanie, Paweł, prowadzący rozległą działalność misyjną w środowisku pogańskim, pozwala sądzić, że z kolei Piotr był jednym z wiodących misjonarzy wśród Żydów. ${ }^{39}$ Zdanie to ogarnia całą dotychczasową działalność obu apostołów. W przypadku Piotra chodzi tu nie tylko o wydarzenia opisane w Dz 9, 32-43, ale o jego prace pośród Żydów z diaspory, podejmowane przez kilka lat

\footnotetext{
35 Zob. Eu ze bi u s z z Ce z a re i, Historia Kościelna III, 36, 2.

36 Tamże, III, 22.

37 M. G r a n t, Święty Piotr, s. 127.

38 Por. K. R o m a n i u k, Św. Piotr, s. 127.

39 Por. J. E c k e r t, Die urchristliche Verkündigung, s. 194.
} 
od opuszczenia Jerozolimy po cudownym uwolnieniu z więzienia (zob. Dz 12, 17) aż do powrotu na Sobór Jerozolimski (Dz 15).

Pewne zdziwienie może budzić fakt, że św. Łukasz, który w Dz 12, 17 nie podał miejsca, do którego Piotr udał się po opuszczeniu Jerozolimy, również nawet jednym zdaniem nie wspomina o pobycie tego apostoła w Antiochii. ${ }^{40}$ Według starożytnej tradycji pochodził on przecież z Antiochii, osobiście znał apostołów głoszących Ewangelię w jego środowisku i na podstawie własnego świadectwa $\mathrm{z}$ wyraźnym entuzjazmem opisał w Dz 11, 19-28 rozwój chrześcijaństwa w swym mieście. Brak wzmianki w Dziejach Apostolskich o pobycie Piotra w Antiochii Syryjskiej nie może z pewnością służyć jako argument za tym, że wydarzenie to nigdy nie miało miejsca. Wiadomo przecież, że św. Łukasz pominął wiele szczegółów także z życia św. Pawła, o których dowiadujemy się np. z 1 Kor 15, 6-7; 2 Kor 11, 24-28; Ga 1, 17-24; 2, 9-10. W Dz 13, 1 nie ma Piotra na liście działających tam proroków i nauczycieli, ponieważ jeszcze tam nie dotarł. To zaś, że również w dalszych częściach swego opowiadania Łukasz nie wspomina o pobycie Piotra w Antiochii i jego konflikcie z Pawłem, może mieć kilka przyczyn. Jak pisze J. Gnilka, może wynikać z widocznej w wielu fragmentach Dziejów Apostolskich intencji ukazania bardzo harmonijnego obrazu pierwotnego Kościoła ${ }^{41}$ (taki m.in. cel miały opisy zawarte w Dz 2-5). Ale może też sugerować, że po ponownym opuszczeniu Judei Piotr nie przybył do stolicy Syrii na dłuższy czas z zamiarem powiększenia licznego grona ewangelizatorów, lecz traktował ją jako przystanek w drodze do Żydów z diaspory, aby po krótkim odpoczynku na nowo podjąć tam przerwaną chwilowo pracę ewangelizacyjną. ${ }^{42}$

Naturalne było, że po przybyciu do tej wspólnoty Piotr włączył się w jej życie religijne, ściśle związane z uczestniczeniem w Eucharystii,

40 Problem ten zauważa np. B. W it h e r i n g t o n III, The Acts of the Apostles, s. 288, przyp. 103.

41 Por. J. G n il k a, Piotr i Rzym. Obraz Piotra w pierwszych $d w u$ wiekach, Kraków 2002, s. 117.

42 Por. S. Ci prian i, Św. Piotr, s. 156. 
która była połączona ze wspólnym posiłkiem osób zgromadzonych na modlitwę (taka Wieczerza Pańska ze wspólną agapą jest opisana np. w 1Kor 11, 17-34). ${ }^{43}$ Choć był uważany za apostoła obrzezanych, to jednak opierając się na własnym doświadczeniu, które wyniósł ze spotkania z setnikiem Korneliuszem (por. Dz 10, 28-35) i które w znacznym stopniu wpłynęło na ostateczną decyzję apostołów i starszych zebranych na Sobór Jerozolimski (Dz 15, 7-11), był otwarty na pogan i jadał z nimi posiłki, narażając się tym samym na spożywanie pokarmów uznawanych przez Prawo Mojżeszowe za nieczyste. Zmiana w sposobie jego postępowania nastąpiła po pojawieniu się w Antiochii osób podzielających poglądy Jakuba, brata Pańskiego, który uważał, że judeochrześcijanie powinni pozostać całkowicie wierni przepisom Prawa Mojżeszowego. ${ }^{44}$ Być może ze zgorszeniem patrzyli oni na łamanie przez Piotra owych przepisów, dlatego apostoł zaczął coraz bardziej unikać poganochrześcijan, postępując zarazem wbrew swoim przekonaniom.

Tekst Ga 2, 11-14 pokazuje, jak wielki autorytet miał już wtedy Piotr nie tylko w Judei, ale też poza jej granicami. Skoro jego postępowanie podjęli też inni chrześcijanie pochodzenia żydowskiego, w tym nawet sam Barnaba, oznacza to, że wpatrywali się w jego zachowanie i traktowali je jak symbol, wzór i przykład do naśladowania, czy też jako punkt odniesienia przy rozwiązywaniu problemów

43 Sytuacja, która doprowadziła do konfliktu Piotra z Pawłem, jest przedstawiana obszerniej w wielu opracowaniach poświęconych wprost temu zagadnieniu; zob. np. J.D.G. D u n n, 'The Incident at Antioch (Gal 2: 11-18), Journal for the Study of New Testament 18/1983, s. 3-57; P.C. B ö $t \mathrm{tg}$ e r, Paulus und Petrus in Antiochien: Zum Verständnis von Galater 2.11-21, New Testament Studies 37/1991, s. 78-81; Ch. B öt $t$ r i c h, Petrus und Paulus in Antiochien (Gal 2,11-21), Berliner Theologische Zeitschrift 19/2002, s. 231-236; H. O r d o n, Autorytet św. Piotra w świetle tzw. konfliktu antiocheńskiego (Ga 2, 11-14), w: S. S z y m i k, H. O r d o n (red.), Opoka Kościoła Chrystusowego. Bibliści KUL w 25. rocznicę pontyfikatu Jana Pawła II, s. 137-138; J.J. G i b s o n, Peter Between Jerusalem \& Antioch: Peter, James \& the Gentiles, WUNT 2/345, Tübingen 2013.

44 Por. C.P. T h i e d e, Simon Pietro, s. 245. 
powstających w Kościele. ${ }^{45}$ Jest zrozumiałe zatem, że Paweł zdecydował się publicznie skarcić wielkiego apostoła, aby wrócił na drogę zgodną z prawdą Ewangelii (w. 14). Jego upomnienie braterskie nie było jednak spowodowane zamiarem osłabienia autorytetu Piotra, lecz troską o prawa i godność chrześcijan pochodzenia pogańskiego. Koncentrując się na tym, że nie należy pogan zmuszać do przyjmowania obyczajów żydowskich, Paweł w swym Liście do Galatów pomija reakcję Piotra. ${ }^{46}$ Jeśli jednak ów incydent antiocheński mógł mu posłużyć za argument za słusznością jego stanowiska, to można się domyślać, że była ona pozytywna i w rezultacie budująca dla całej wspólnoty wierzących. ${ }^{47}$

\section{Apostolska działalność Piotra w Azji Mniejszej}

W 1P 1, 1,Piotr, apostoł Jezusa Chrystusa”, oznajmia, że pisze „do wybranych, przybyszów wśród rozproszenia w Poncie, Galacji, Kapadocji, Azji i Bitynii". Nawiązując do tego tekstu, Euzebiusz z Cezarei pisze po wzmiance o misjonarskim dziele Pawła od Jerozolimy aż po Ilirię: „Również ze słów Piotra widać, w jakich prowincjach głosił Ewangelię Chrystusa tym, którzy pochodzą z obrzezania, wykładając im naukę Nowego Testamentu, a widać to przede wszystkim z Listu, który, jak powiedziałem, jest powszechnie uznany za autentyczny. Pisze w nim do wiernych pochodzenia żydowskiego, żyjących w diasporze w Poncie, Galacji, Kapadocji, Azji i Bitynii". ${ }^{48}$

45 Por. H. Ordo n, Autorytet św. Piotra, 138-141; S. C i p r i a n i, Św. Piotr, s. 159-160; P. M e lc z e w s k i, Niewłaściwe postępowanie Piotra w Antiochii (Ga 2, 14), RBL 58/2005, s. 276.

46 Por. S. Ci prian i, Św. Piotr, s. 159.

47 Do podobnego wniosku dochodzi też w swej analizie D. M a t a k, Another Look at the Antioch Incident (Gal 2:11-14), Kairos, Evangelical Journal of Theology 6/2012, s. 57.

48 Euzebiusz z Cezare i, Historia Kościelna 3, 4, 2 (podobna informacja jest też w 3, 1, 2). Tekst polski w: t e n ż e, Historia Kościelna, tłum. A. C a b a (na podstawie tłum. A. L i s i e c k i e g o), Kraków 2013, s. 145. 
Choć niektórzy współcześni egzegeci kwestionują autentyczność Pierwszego Listu św. Piotra, a inni uważają, że za jego powstanie jest odpowiedzialne grono najbliższych współpracowników apostoła (tzw. grupa Piotrowa), ${ }^{49}$ to jednak wielu wciąż podtrzymuje zdanie, iż nie ma wystarczających argumentów, by podważać Piotrowe autorstwo tego pisma. ${ }^{50}$ Jednakże przyjmując zarówno podyktowanie listu przez samego Piotra, jak też udział jego uczniów w ostatecznym zredagowaniu pisma, nasuwa się pytanie, dlaczego jego adresatami są chrześcijanie z tych właśnie prowincji Azji Mniejszej, a nie z Jerozolimy lub Antiochii, gdzie apostoł ten był dobrze znany i miał ogromny autorytet. Paweł swe listy kierował do najbliższych współpracowników (Tymoteusza, Tytusa i Filemona), do wspólnot, które sam założył (Filipian, Tesaloniczan, Koryntian, Efezjan i Galatów), bądź też do Kościołów, które powstały z inicjatywy jego najbliższych współpracowników i w których był uznawany jego autorytet apostolski (Kolosy). W tym względzie wyjątkiem nie jest nawet List do Rzymian, ponieważ wśród tych adresatów było wielu jego współpracowników lub znajomych (zob. Rz 16, 3-15), do których zamierzał niebawem się udać, traktując Rzym jako przystanek w drodze do Hiszpanii $(15,24)$. Czy na zasadzie analogii można stwierdzić, że również Piotr napisał swój list do tych, którzy go znali i uznawali za swego apostoła?

Wszystkie wymienione w 1P 1, 1 prowincje znajdują się w północnej części Azji Mniejszej. W Dz 2, 9 Łukasz pisze, że na święto Pięćdziesiątnicy przybyli m.in. Żydzi z Kapadocji, Pontu i Azji. Zarówno

49 Por. S. H ał a s, Pierwszy List św. Piotra. Wstęp, przekład z oryginału, komentarz, Nowy Komentarz Biblijny NT 17, Częstochowa 2007, s. 24-29. Problem ten dotyczy też Drugiego Listu św. Piotra. Odnośnie do tego zob. F. M i c k i e w i c z, Gtówne tematy teologiczne Drugiego Listu św. Piotra, Collectanea Theologica 88 (2018) nr 1, s. 23-42.

50 Zob. np. S. M c K n ig h t, 1 Peter, The NIV Application Commentary, Grand Rapids 1996, s. 28; Th.R. S c h r e i n e r, 1, 2 Peter, Jude, The New American Commentary 37, Nashville 2003, s. 35-36; K.H. J o b e s, 1 Peter, Baker Exegetical Commentary on the New Testament, Grand Rapids 2005, s. 19; D.F. W a t s o n, T. C a 11 a n, First and Second Peter, Grand Rapids 2012, s. 5. 
ta informacja, jak też dane pozabiblijne i archeologiczne wskazują na to, że na tych terenach była rozwinięta diaspora żydowska, która przyciągała do synagogi pochodzących ze środowiska pogańskiego bojących się Boga i prozelitów i stała się też kolebką pierwszych wspólnot chrześcijańskich. ${ }^{51} \mathrm{Z} \mathrm{Dz} \mathrm{14,} \mathrm{1;} \mathrm{17,} \mathrm{1-2.} \mathrm{10.} \mathrm{17;} \mathrm{18,} \mathrm{4.} \mathrm{19;} \mathrm{19,} 8$ dowiadujemy się, że św. Paweł udawał się przede wszystkim do tych miast, w których była liczna diaspora żydowska, a tam uprzywilejowanym miejscem głoszenia Ewangelii stawały się synagogi. Gdy jednak w czasie drugiej podróży misyjnej zamierzał pójść do Azji, a potem do Bitynii, Duch Święty zabronił im głosić Ewangelię w tych krainach (Dz 16, 6-7). Również nigdy nie dotarł do Pontu i Kapadocji, a w Dz 16, 6 czytamy, że on i jego towarzysze, przynaglani przez Ducha Świętego, przeszli pośpiesznie przez „krainę galacką”. Dopiero z Ga 4, 13 można się dowiedzieć, że wśród Galatów zatrzymał się na krótko z powodu choroby i czas ten wykorzystał do głoszenia im Ewangelii, ale śledząc trasę jego podróży, można przypuszczać, że wędrował tylko przez południową część Galacji. Wreszcie podczas trzeciej podróży misyjnej przez trzy lata mieszkał w Efezie, stolicy rzymskiej prowincji noszącej nazwę Azja, ale nic nie wiemy, czy kiedykolwiek opuścił go, by głosić Ewangelię także w okolicznych miastach.

Jak widać, św. Paweł w swych podróżach misyjnych na polecenie samego Ducha Świętego zupełnie lub prawie zupełnie pominął krainy wymienione w 1P 1, 1. Co więcej, pisząc List do Rzymian pod koniec trzeciej podróży misyjnej, wyznawał: „A poczytywałem sobie za punkt honoru głosić Ewangelię jedynie tam, gdzie imię Chrystusa było jeszcze nieznane, by nie budować na fundamencie położonym przez kogoś innego" (Rz 15, 20). Czy w kontekście tych słów można postawić hipotezę, że św. Paweł nie udał się do Bitynii i innych krain

51 Por. J.H. E 11 i o t t, 1 Peter. A New Translation with Introduction and Commentary, The Anchor Bible 37B, New York 2000, s. 84-93; S. H a $\nmid$ a s, Pierwszy List św. Piotra, s. 38-39; M.W. W i 1 s o n, Cities of God in Northern Asia Minor: Using Stark's Social Theories to Reconstruct Peter's Communities, Verbum et Ecclesia 32/2011, s. 7-8. 
położonych w północnych i wschodnich częściach Azji Mniejszej, ponieważ tam już istniały wspólnoty chrześcijańskie, założone przez św. Piotra lub przez innego apostoła? Pytanie to stawiają niektórzy uczeni, choć na podstawie samych danych biblijnych nie są w stanie udzielić na nie jednoznacznej odpowiedzi. ${ }^{52}$ Jak się jednak wydaje, można dostrzegać związek Dz 16, 6-7 i Rz 15, 20 z 1P 1, 1 oraz odpowiedzieć na to pytanie pozytywnie. Skoro Duch Święty jest Mądrością Bożą, musiał mieć jakiś ważny powód, by zakazać głoszenia Ewangelii w Azji, Bitynii i na innych północnych terytoriach Azji Mniejszej. Taką uzasadnioną przyczyną mogła być właśnie prowadzona w tych krainach działalność Piotra i jego uczniów. ${ }^{53}$

Gdyby ani Piotr, ani też jego uczniowie nigdy nie pojawili się na tych terenach, trudno byłoby uzasadnić rangę jego imienia, którą da się zauważyć w jego pierwszym liście. Jeszcze bardziej zastanawiające jest jego niepodważalne znaczenie w Liście do Galatów. Paweł aż 5 razy powołuje się w nim na osobę Piotra, aby uzasadnić własny autorytet apostolski lub prawdziwość głoszonej przez niego Ewangelii (Ga1,18;2, 7.8.9.14). Również gdy w 2, 11 pisze, że w Antiochii sprzeciwił się Piotrowi, dodaje: ,...bo na to zasłużył”, usprawiedliwiając się tym sposobem przed Galatami, dlaczego odważył się upomnieć nawet Piotra. Kiedy Paweł pisał ten list, nie było jeszcze ani Ewangelii ukazujących rolę Piotra w gronie Dwunastu, ani Dziejów Apostolskich, opisujących ożywioną działalność Piotra we wspólnocie jerozolimskiej, ani żadnego oficjalnego pisma świadczącego o jego wysokiej randze w całym Kościele Chrystusowym. Dla Galatów zatem mógł stać się on punktem odniesienia tylko dlatego, że przybył do nich, głosił wśród nich Ewangelię i dał się poznać jako autorytet. Paweł, oczywiście, głosząc Galatom Ewangelię o Chrystusie w czasie

52 Zob. np. M.-L. L a m a u, Des chrétiens dans le monde. Communautés pétriniennes au Ier siècle, Lectio Divina 134, Paris 1988, s. 40.

53 Por. E.G. S e 1 w y n, The First Epistle of St. Peter: The Greek Text with Introduction, Notes and Essays, London 1981², s. 131; Ch. B ig g, A Critical and Exegetical Commentary on the Epistles of St. Peter and St. Jude, Edinburgh 1987, s. 73. 
swej drugiej podróży misyjnej, musiał też wspominać o apostole Piotrze, ale taka „teoretyczna” wiedza o jego osobie raczej nie mogła spowodować, by również Galaci traktowali go jako jeden z filarów Kościoła (por. Ga 2, 9).

Jest zatem możliwe, że podczas gdy św. Paweł głosił Ewangelię w południowej i zachodniej Azji Mniejszej, Piotr wędrował przez jej północne obszary i zakładał tam wspólnoty chrześcijańskie, ${ }^{54}$ lecz ze względu na ogromne odległości nie mogli kontaktować się ze sobą. W tym względzie Euzebiusz z Cezarei, którego świadectwo przejmuje też św. Hieronim, ${ }^{55}$ może mieć rację, że sam Piotr we wstępie swego listu wyjawia, w jakich prowincjach głosił Żydom Ewangelię, zanim dotarł do Rzymu. ${ }^{56}$ Ma oczywiście rację N. Brox, że zakreślony w 1P 1, 1 krąg adresatów jest niemal utopijnie wielki. ${ }^{57}$ Trzeba jednak pamiętać, że pismo to ma wyraźnie charakter listu powszechnego (okólnego), który być może dostarczył chrześcijanom w Poncie, Galacji, Kapadocji, Azji i Bitynii Sylwan wymieniony w 1P 5, 12. Nawet kolejność wymienionych tu krain odpowiada drodze, którą musiał przebyć kurier, idąc od jednego miasta do drugiego, aby dostarczyć list do poszczególnych wspólnot, ${ }^{58}$ które znały Piotra i za które Piotr

54 Taką możliwość lub przynajmniej jedną z kilku możliwości przyjmują np. R.E. B r o w n, J.P. M e i e r, Antioch and Rome: New Testament Cradles of Catholic Christianity, New York 1983, s. 131; P.H. D a v i d s, The First Epistle of Peter, The New International Commentary on the New Testament, Grand Rapids 1990, s. 8; Th. K le i n, Bewährung in Anfechtung: der Jakobusbrief und der Erste Petrusbrief als christliche Diaspora-Briefe, Tübingen 2011, s. 235; H.A. K e n t, D.R. D 111 i n g, The First Epistle of Peter. A Translation and Exegetical Study, Lafayette 2014, s. 37, przyp. 2.

55 Św. Hi eron i m, O znakomitych mężach 1.

56 W prawdziwość tej informacji wątpi P. K e t t e r, Hebräerbrief, Jakobusbrief, Petrusbriefe, Judasbrief, Herders Bibelkommentar. Die Heilige Schrift für das Leben erklärt 16/1, Freiburg 1950, s. 203, ale nie podaje żadnych argumentów na poparcie swego stanowiska.

57 N. B r o x, Der erste Petrusbrief, Leipzig 1987², s. 56.

$58 \mathrm{Na}$ fakt ten zwraca uwagę wielu uczonych. Zob. szerzej D.E. H i e b e r t, Designation of the Readers in 1 Peter 1:1-2, Bibliotheca Sacra S 137/1980, s. 64-75; J.H. E 11 i o t t, 1 Peter, s. 91-93; Th.R. S c h r e i n e r, 1, 2 Peter, Jude, s. 37; S. H ał a s, 
czuł się duchowo odpowiedzialny. Z nazw tych pięciu krain nie wynika, że Piotr swoją działalnością objął całą ludność północnej Azji Mniejszej. Można założyć, że głosił Ewangelię tylko w niektórych miastach, do których zdołał dotrzeć, a chrześcijaństwo (podobnie jak to było w ewangelizacyjnej misji św. Pawła) gwałtownie się rozprzestrzeniało niejako własną siłą, dzięki pracy nawróconych przez niego gorliwych chrześcijan, którzy jako jego uczniowie i powołując się na jego autorytet, dalej rozpowszechniali Ewangelię o Jezusie Chrystusie, Zbawicielu. ${ }^{59} \mathrm{Na}$ podstawie znanych nam skąpych śladów i poszlak nie można jednak ustalić, przez jaki czas lub dokładnie w jakich latach Piotr był obecny na tamtym terytorium.

\section{Wizyta Piotra w Koryncie}

Euzebiusz z Cezarei w Historii Kościelnej cytuje Dionizego, biskupa korynckiego, który w swym Liście do Rzymian pisze, że Piotr i Paweł w Koryncie zasadzili szczep Kościoła Chrystusowego i jego mieszkańcom głosili naukę. ${ }^{60}$ To zasadzenie szczepu jest oczywiście metaforą założenia Kościoła. Takie sformułowanie rodzi jednak problem, ponieważ z Dz 18, 1-11 oraz z 1Kor 3, 6. 10; 4, 15 się dowiadujemy, że założycielem chrześcijańskiej wspólnoty w Koryncie był św. Paweł, podczas gdy o działalności św. Piotra w tym mieście zupełnie nie ma tam mowy. Czy to by oznaczało, że to bardzo wczesne, gdyż pochodzące z 2. połowy II wieku, świadectwo Dionizego z Koryntu całkowicie mijało się z prawdą?

Godne uwagi w tym kontekście jest to, że w Pierwszym Liście do Koryntian imię Piotra w jego pierwotnym, aramejskim brzmieniu (czyli Kefas), pojawia się cztery razy. Po raz pierwszy i w naszym

Pierwszy List św. Piotra, s. 41; J. K r ę c i d ł o, Sytuacja społeczna i religijna adresatów Pierwszego Listu św. Piotra, w: W. C h r o s t o w s k i, B. S t r z a ł k o w s k a (red.), „Patrzmy na Jezusa, który nam w wierze przewodzi”. Księga pamiatkowa dla Księdza Profesora Jana Eacha w 85. rocznicę urodzin, Warszawa 2012, s. 340.

59 Por. K.H. S c h e 1 k 1 e, Die Petrusbriefe. Der Judasbrief, Herders Theologischer Kommentar zum Neuen Testament 13/2, Freiburg-Basel-Wien 1965, s. 2.

${ }^{60}$ Euzebiusz z Cezarei, Historia Kościelna 2, 25, 8 . 
kontekście w sposób najbardziej znaczący św. Paweł pisze o Piotrze, gdy ostro gani podziały, które po jego odejściu z Koryntu pojawiły się w tamtejszej wspólnocie i które jej członkowie wyrażali stwierdzeniem: „Ja jestem Pawła, a ja Apollosa; ja jestem Kefasa, a ja Chrystusa" (1Kor 1, 12). Niektórzy egzegeci są zdania, że w tych wypowiedziach występuje genetivus relationis, który wyraża relacje między małżonkami (,ja jestem żoną kogoś”) lub między dziećmi a ich rodzicami. ${ }^{61}$ Inni uważają, że wskazuje on na przynależność jakiejś osoby do określonej partii politycznej albo ugrupowania skupionego wokół lidera cieszącego się w Koryncie dużym autorytetem ${ }^{62}$ (,ja opowiadam się za Pawłem, a ja za Apollosem” lub ,ja naśladuję Pawła, a ja Apollosa"63). Jeszcze inni twierdzą, że zachodzi tu genetivus possesionis, który można przetłumaczyć: ,Ja należę do ..." ${ }^{64}$

Wszystkie te tłumaczenia mogą wskazywać na specyficzną postawę każdej z grup, opowiadającej się za jednym z apostołów, ale w niniejszym artykule nie są one przedmiotem analizy. W tym miejscu należy natomiast zauważyć, że wskazywane przez Koryntian osoby nie były odpowiedzialne za istniejące w ich wspólnocie podziały. ${ }^{65}$ Ich przyczyną nie była też różnica poglądów Pawła, Apollosa i Kefasa (skoro sam Paweł w 1Kor 3, 1-4, 2 wyjaśnia, że wszyscy apostołowie są wiernymi sługami Chrystusa), ale zapewne odmienny sposób nauczania i przekazywania tych samych prawd. ${ }^{66}$ Sam św. Paweł pisał o sobie, że jego głoszenie nauki Koryntianom nie miało „nic z uwodzących przekonywaniem słów mądrości”, lecz

${ }_{61}$ Por. M.M. M it c h e 11, Paul and the Rhetoric of Reconciliation, Louisville 1992, s. 85.

62 L.L. W e 1 b o r n, Politics and Rhetoric in the Corinthian Epistles, Macon 1997, s. 7-16.

63 To ostatnie thumaczenie 1Kor 1, 12 („I follow Paul”) jest obecne m.in. w New International Version.

${ }^{64}$ Takie tłumaczenie można znaleźć np. w The New Jerusalem Bible oraz w New Revised Standard Version.

65 Por. N.A. D a h 1, Studies in Paul, Minneapolis 1977, s. 40-61.

${ }^{66}$ Por. G. R a fi ń s k i, Problem przeciwników św. Pawła w 1 Kor, STV 23 (1985) nr 2, s. 156. 
było „ukazywaniem ducha i mocy” (1Kor 2, 4). O Apollosie wiadomo z Dz 18, 24-28, że jako „uczony i znający świetnie Pisma” wykazywał na ich podstawie, „że Jezus jest Mesjaszem”. Występował zatem jako apologeta broniący wiary i nauki chrześcijańskiej. ${ }^{67}$ Święty Piotr natomiast reprezentował palestyńskie korzenie Kościoła pierwotnego oraz grono jego filarów (por. Ga 2, 9), być może więc z nim utożsamiali się Żydzi nawróceni na chrześcijaństwo. ${ }^{68}$

Ponieważ ani w Dziejach Apostolskich, ani w obu listach do Koryntian nie ma wprost żadnej wzmianki o pobycie św. Piotra w tej wspólnocie, egzegeci na kilka różnych sposobów wyjaśniają 1Kor 1, 12. Wśród nich pojawia się nawet głos, że prawdopodobnie w tekście tym św. Paweł przesadnie wyolbrzymia gorszące podziały w Koryncie i je personalizuje, aby ukazać ich absurdalność. ${ }^{69}$ Niektórzy z nich sugerują, że imię Kefasa (Piotra) jest szyldem „dla tej grupy chrześcijan korynckich, którzy uprzywilejowali tradycję judejską (w odróżnieniu od poganochrześcijańskiej)". ${ }^{70} \mathrm{Z}$ kolei inni uczeni jedynie stwierdzają w swych komentarzach, że nie da się wykazać, iż św. Piotr przebywał w tym mieście, i dalej nie zajmują się tym zagadnieniem. ${ }^{71}$ Jest jednak wielu egzegetów, którzy podejmują

${ }^{67}$ Dyskusję uczonych, dotyczącą natury ugrupowania Apollosa, przedstawia A.C. Th is elt o n, The First Epistle to the Corinthians: A Commentary on the Greek Text, Grand Rapids 2000, s. 123-125.

${ }^{68}$ Por. G.T. M o n t a g u e, First Corinthians, Catholic Commentary on Sacred Scripture, Grand Rapids 2011, s. 38; F. M a n z i, Prima Lettera ai Corinzi. Introduzione, traduzione e commento, Cinisello Balsamo 2013, s. 48.

69 W.F. O r r, J.A. W a 1 t h e r, I Corinthians. A New Translation, Introduction with a Study of the Life of Paul, Notes and Commentary, The Anchor Bible 32, New York 1976, s. 148.

70 M. R o s i k, Pierwszy List do Koryntian. Wstep, przekład z oryginału, komentarz, Nowy Komentarz Biblijny NT 7, Częstochowa 2009, s. 120.

${ }_{71}$ Zob. np. H. La n g k a m m e r, Pierwszy i Drugi List do Koryntian, Biblia Lubelska, Lublin 1998, s. 22; A. R o b e r t s o n, A. P 1 u m m e r, A Critical and Exegetical Commentary on the First Epistle of St Paul to the Corinthians, Edinburgh 1999, s. 12; D.E. G a r 1 a n d, 1 Corinthians, Grand Rapids 2003, s. 45; R.B. H a y s, First Corinthians, A Bible Commentary for Teaching and Preaching, Louisville 2011, s. 22. 
ten problem i podają wiele przekonywających argumentów za możliwością jego pobytu w Koryncie. ${ }^{72}$

O tym, że Koryntianie znali Piotra i uznawali jego autorytet, może świadczyć kilkakrotne odwołanie się do jego osoby w Pierwszym Liście do Koryntian. ${ }^{73}$ Najpierw należy stwierdzić, że w 1Kor 1, 10-16 św. Paweł wymienia po imieniu tylko te osoby, które były osobiście znane adresatom listu: Chloe, Apollosa, Kryspusa, Gajusa i Stefanasa. Stronnictwa Pawła i Apollosa opowiadały się za apostołami, którzy rzeczywiście byli w Koryncie i prowadzili tam ożywioną działalność. Zestawienie tych stronnictw z osobami, które mówiły: „Ja jestem Kefasa”, oraz umieszczenie tego imienia w kontekście postaci przebywających na stałe w Koryncie pozwala sądzić, że również Kefas (Piotr) był znany Koryntianom z bezpośredniego kontaktu z jego osobą. ${ }^{74}$ Wniosek taki potwierdza 1Kor 3, 21-22, gdzie Paweł pisze: „Niech się przeto nie chełpi nikt z powodu ludzi. Wszystko bowiem jest wasze: czy to Paweł, czy Apollos, czy Kefas". Ganiąc podziały istniejące między tymi, którzy mówili o sobie, że należą do Pawła, Apollosa lub Kefasa, Paweł odwraca porządek rzeczy i oświadcza, że w rzeczywistości apostołowie ci należą do wyznawców Chrystusa, czyli są sługami i pomocnikami Boga w budowaniu i umacnianiu Kościoła Chrystusowego (zob. 1Kor 3, 5-9; 4, 1). Również taki sposób pisania zakłada osobiste więzi istniejące między Piotrem a Koryntianami.

72 Argumenty te przedstawiają zwięźle m.in. K. R o m a n i u k, Czy święty Piotr działat na terenie Koryntu? RTK 22 (1975) nr 1, s. 104-106; W.M. R a m s a y, Historical Commentary on First Corinthians, Grand Rapids 1996, s. 151-155; A.C. T h i s e 1 t o n, The First Epistle to the Corinthians, s. 128-129.

73 Por. G.T. M o n t a g u e, First Corinthians, s. 38.

74 Por. W.M. R a m s a y, Historical Commentary, s. 152; J. G n il k a, Piotr i Rzym, s. 106; J.A. F i t z m y e r, First Corinthians. A New Translation with Introduction and Commentary, The Anchor Yale Bible 32, New Haven-London 2008, s. 144. J. Gnilka uważa, że Piotr być może „także ochrzcił kilka osób w Koryncie. Bo tutaj poczucie przynależności ochrzczonych do szafarza chrztu było szczególnie silne" (J. G n i 1 k a, Piotr i Rzym, s. 107). Podobny pogląd wypowiada też W.A. B e a r d s l e e, First Corinthians: A Commentary for Today, St. Louis 1994, s. 24. 
W 1Kor 9, 5 Paweł ukazuje jako wzór apostolskie metody innych apostołów i braci Pańskich, przy czym z tego grona autorytetów jerozolimskiego judeochrześcijaństwa wyróżnia Kefasa, wymieniając tylko jego po imieniu. Paweł, który był bezżenny, zwraca uwagę na to, że owi apostołowie zabierają ze sobą niewiasty-siostry. Zastosowane tu przez Pawła określenie adelfē-gynē nie jest do końca jasne. Wielu uważa, że chodzi tu po prostu o żonę, ponieważ w środowisku zarówno żydowskim, jak i greckim, nie było zwyczaju, by o materialne sprawy mężczyzny troszczyła się kobieta nie będąca jego żoną ${ }^{75}$ Jednakże w wywodzie św. Pawła jest ważne nie tyle rozumienie tego określenia, ile fakt, że wspólnoty chrześcijańskie udzielały gościnności nie tylko apostołom, ale też ich towarzyszkom (por. 1Kor 9, 4). Jego sposób pisania zakłada, że Koryntianie z własnego doświadczenia znali styl życia oraz misjonarskie metody Piotra. Osobiście mogli się przekonać, że były one nieco inne od Pawłowych, a ponieważ w oczach Koryntian Piotr uchodził za wielki autorytet, Paweł oświadcza, że on też miałby prawo postępować tak jak on i domagać się dla siebie utrzymania, ale mimo wszystko tego nie czyni. ${ }^{76}$ Ze względu również na ten autorytet pod koniec swego listu, w wywodzie na temat prawdziwości zmartwychwstania umarłych, przypomina swym adresatom prawdę o tym, że Kefas jest jednym $\mathrm{z}$ uprzywilejowanych świadków Chrystusa zmartwychwstałego (1Kor 15, 5).

Wszystkie te argumenty wskazują na to, że przed powstaniem Pierwszego Listu do Koryntian św. Piotr złożył wizytę chrześcijanom w stolicy Achai, kiedy Paweł przez trzy lata przebywał w Efezie. ${ }^{77}$

75 Odnośnie do tego zob. M. R o s i k, Pierwszy List do Koryntian, s. 297.

76 Por. G.D. F e e, The First Epistle to the Corinthians, The New International Commentary on the New Testament, Grand Rapids 1987, s. 57; W.M. R a m s a y, Historical Commentary, s. 151.

77 Taką możliwość dopuszcza wielu autorów: M. G o g u e 1, L'Apôtre Pierre a-t-il joué un rôle personnel dans les crises de Grèce et de Galatie? Revue d'histoire et de philosophie religieuses 14/1934, s. 469-470; C.K. B a r r e t t, Cephas and Corinth, w: O. B e t z (red.), Abraham unser Vater: Juden und Christen im Gespräch über die Bibel: Festschrift für Otto Michel, Leiden 1963, s. 1-12; P. V i e 1 h a u e r, Paulus und die Kephaspartei in Korinth, New Testament Studies 21/1975, s. 344; 
Jest bardzo prawdopodobne, że Piotr zatrzymał się w Koryncie, podążając z Azji Mniejszej do Rzymu. W takim przypadku najbardziej dogodna podróż prowadziła z portu w Efezie, ponieważ w tamtym czasie często kursowały statki między Efezem a Koryntem. ${ }^{78}$ Ale również gdy płynął z Syrii, ważne znaczenie miało to, że Korynt znajdował się w połowie drogi między Palestyną a Rzymem i dla wielu osób stanowił dobre miejsce na odpoczynek. ${ }^{79}$ Jest pewne, że nie był założycielem gminy korynckiej, o tym jednak, jaki charakter miała jego wizyta w tamtej wspólnocie oraz jak doszło do powstania w niej ugrupowania powołującego się na jego imię, nie da się powiedzieć nic konkretnego.

$$
* * *
$$

Historycy i teolodzy katoliccy są zgodni co do tego, że św. Piotr pod koniec swego życia przez kilka lat przebywał w Rzymie i w nim poniósł śmierć męczeńską za panowania Nerona, ale w świetle zawartych w tym artykule analiz można stwierdzić, że droga, którą przebył, zanim tam dotarł z Jerozolimy, była długa. Chociaż dane biblijne na ten temat są skąpe, to jednak pozwalają przypuszczać, że po opuszczeniu Judei w 42 r. za panowania Heroda Agryppy I stał się on wędrownym apostołem i prowadził działalność misjonarską w różnych diasporach żydowskich ówczesnego Cesarstwa Rzymskiego. W Nowym Testamencie wskazują na to cztery krótkie teksty. Tekst Ga 2, 11-14 jest jednoznacznym świadectwem tego, że po Soborze Jerozolimskim św. Piotr udał się do Antiochii Syryjskiej, gdzie przez

J. K r e m e r, Der erste Brief an die Korinther übersetzt und erklärt, Regensburg 1997, s. 32; A. L i n d e m a n n, Der erste Korintherbrief, Handbuch zum Neuen Testament 9/1, Tübingen 2000, s. 39-40; J.A. F i t z m y e r, First Corinthians, s. 144; S. C i pri a n i, Św. Piotr, s. 178; M. He n g e 1, Saint Peter: The Underestimated Apostle, Grand Rapids 2010, s. 67.

78 Por. W.M. R a m s a y, Historical Commentary, s. 152-153.

79 S. D o c k x, Essai de chronologie pétrinienne, uważa, że Piotr złożył wizytę w Koryncie płynąc do Rzymu już w 42-43 r., co - jak już zostało wykazane - jest mało prawdopodobne. 
jakiś czas ewangelizował zarówno Żydów, jak też pogan. Natomiast 1P 1, 1 może być reminiscencją jego działalności w północnych regionach Azji Mniejszej, a 1Kor 1, 12; 9, 5 sugeruje, że złożył wizytę chrześcijanom w Koryncie podczas swej podróży do Rzymu. Teksty te oczywiście należy traktować nie tyle jako dowód, ile jako poszlakę prowadzącą do ogólnego wniosku, że również św. Piotr wypełnił na swój sposób misyjny nakaz Jezusa, by Jego apostołowie szli na cały świat i głosili Ewangelię wszelkiemu stworzeniu (por. Mk 16, 15). To by zaś oznaczało, że jego autorytet nie tylko opierał się na przekazaniu mu władzy kluczy (por. Mt 16,19) i pobycie w Rzymie, ale też zrodził się dzięki gorliwej pracy apostolskiej, dzięki której mogli go osobiście spotkać, poznać i docenić chrześcijanie z wielu ważnych w owym czasie Kościołów lokalnych w Palestynie, Azji Mniejszej i Grecji.

\section{Franciszek MICKIEWICZ SAC}

Słowa kluczowe: św. Piotr; apostolstwo; podróże misyjne

Keywords: Saint Peter; apostolate; missionary journeys

\section{Missionary Activities of Saint Peter outside Palestine in the Light of the New Testament Literature}

\section{Summary}

In this article an attempt is made at answering the question of where Peter was able to stay and act. It considers the time from when Peter left Jerusalem in the year 42 (Acts 12:17) to his arrival in Rome. The analysis of Galatians 2:11-14 leads to the conclusion that after the Jerusalem Council he certainly spent some time in Antioch. It is possible that during his many years of travel he reached the northern regions of Asia Minor. We find reminiscence of this in 1 Peter 1:1. Later, on the way to Rome, he probably visited Christians in Corinth as can be seen in 1 Corinthians 12:9,5. These texts allow the supposition that, after leaving Jerusalem, Peter became an itinerant apostle, led extensive missionary activity, and, through personal contacts with Christian communities, obtained great authority among them. 